\title{
DAMPAK KAWASAN INDUSTRI DI DESA BUTUH TERHADAP PEREKONOMIAN DAN KEINGINAN BERWIRAUSAHA DI KECAMATAN MOJOSONGO, BOYOLALI
}

\author{
Nurul Istiqomah ${ }^{1)}$, Dwi Prasetyani ${ }^{2)}$, Amina Sukma Dewi ${ }^{3)}$ \\ ${ }^{1}$ Fakultas Ekonomi dan Bisnis, Universitas Sebelas Maret \\ Email : nurulistiqomah1980@yahoo.com \\ ${ }^{2}$ Fakultas Ekonomi dan Bisnis, Universitas Sebelas Maret \\ Email : nd_prasetyani@yahoo.com \\ ${ }^{3}$ Fakultas Ekonomi dan Bisnis, Universitas Sebelas Maret \\ Email : dewiyaa@yahoo.co.id
}

\begin{abstract}
This background of this research is the establishment of several factories in Butuh Village, Mojosongo Sub-District, Boyolali Regency, which forms an industrial area. In the past, the residents of Butuh Village worked by cultivating land and breeding livestock because the soil in this area is barren and water sources are difficult to find. Because of the establishment of industrial area, the economic activity of this area increases significantly.

This research uses descriptive-quantitative research method. Qualitative analysis is used to discover the increase of economic activity and the level of health and education of the surrounding community. Whereas quantitative analysis was conducted by using Paired Samples T test. This test is used to discover the presence of average difference between two paired (corresponding) sample groups. In this case, it is about community's income and expenditure in the surroundings of industrial area. Whereas regression analysis, specifically Ordinary Least Square(OLS) Logit, is used to discover community's entrepreneurship desire after the existence of industrial area.

The impact of industrial area in Butuh Village, Mojosongo Sub-district can reduce unemployment rate. However,most people in Butuh Village prefer becoming entrepreneurs around the industrial area to factory workers. Additional income earned shifts the way of thinking of people around industrial area in the field of education and health. In addition, there were differences of income and expenditure between the times before and after the existence of industrial area in Butuh Village. The last, education, income and expenditure influence the entrepreneurial decision.
\end{abstract}

Key words: Industrial Area, Income, Expenditure, Paired Samples T-test, Logit. 


\section{PENDAHULUAN}

Struktur perekonomian di Indonesia sudah mulai mengalami pergeseran. Hal tersebut merupakan suatu yang wajar yang dialami oleh setiap negara di seluruh dunia. Data mengenai kontribusi masingmasing sektor terhadap PDB bisa memberikan gambaran, bahwa pada tahun 1969 struktur perekonomian di Indonesia masih didominasi oleh sektor pertanian, dimana kontribusi sektor pertanian adalah sebesar 49,3\% dan semakin lama kontribusinya mengalami penurunan. Pada tahun 1979 sumbangsih sektor pertanian menjadi $28,1 \%$ dan terus menurun hingga data yang diperoleh pada tahun 2011 kontribusinya hanya $14,7 \%$. Penurunan kontribusi sektor pertanian terhadap PDB disebabkan pengurangan lahan-lahan pertanian yang ada di Pulau Jawa, adanya kegagalan panen, kegagalan untuk membuka lahan pertanian baru di luar Pulau Jawa yang disebabkan tingkat kesuburan tanah yang berbeda dengan Pulau Jawa.

Ketika sektor pertanian mengalami penurunan, sektor industri cenderung mengalami kenaikan. Pada tahun 1969, kontribusi sektor industri pengolahan hanya 9,2 \%, masih kalah jauh jika dibandingkan dengan sektor pertanian dan perdagangan yang kala itu mencapai $30 \%$. Sektor industri pengolahan pada tahun 1979 angkanya sudah naik menjadi 10,3\% dan satu dekade berikutnya menjadi $18,4 \%$. Pada tahun 2008, kontribusinya mencapai $27,8 \%$ dan hingga data tahun 2012 Semester I diperoleh data kontribusi sektor industrI pengolahan sebesar 23,6\%.

Pertumbuhan sektor industri di Indonesia masih ditopang oleh 3 sektor industri, yaitu industri makanan, alat angkut dan tekstil. Ketiga sektor industri tersebut berkontribusi hampir $70 \%$ terhadap pertumbuhan industri di Indonesia. Menurut Dedi Mulyadi, Dirjen Pengembangan dan Perwilayahan Kementrian Perindustrian, berpendapat bahwa peningkatan daya saing industri merupakan salah satu kebijakan yang dilakukan untuk meningkatkan daya saing industri baik di dalam maupun di luar negeri. Untuk menjadi industri yang mempunyai daya saing yang bagus, maka pembangunan sektor industri harus memaksimalkan potensi sumber daya yang dimiliki oleh daerah.

Boyolali merupakan salah satu kabupaten di Propinsi Jawa Tengah yang pertumbuhan ekonominya mempunyai potensi untuk terus meningkat. Berdasarkan data dari BPS, pertumbuhan ekonomi Kabupaten Boyolali pada tahun 2008 adalah 4,04\% sedangkan pada tahun 2009 meningkat menjadi $5,16 \%$. Ada empat sektor yang memberikan kontribusi di atas 10\% terhadap PDRB Kabupaten Boyolali pada tahun 2010, yaitu sektor pertanian sebesar 37,18\%; sektor perdagangan sebesar 23,93\%; sektor industri pengolahan sebesar 14,15 \%; dan sektor jasa-jasa sebesar $11 \%$. Khusus untuk sektor industri, perkembangannya begitu pesat di Kabupaten Boyolali.

Kecamatan Mojosongo merupakan salah satu kecamatan yang ada di Kabupaten Boyolali dan termasuk kecamatan yang perekonomiannya mengalami kemajuan yang pesat. Hal ini dilatarbelakangi karena munculnya banyak perusahaan tekstil di kawasan tersebut, sehingga menyebabkan masyarakat yang bermata pencaharian di sektor industri sebanyak $17 \%$, dan posisi pertama masih ditempati petani sebanyak $52 \%$. Kecamatan Mojosongo terdiri dari 13 desa, dan salah satunya adalah Desa Butuh. Di Desa Butuh terdapat beberapa perusahaan yaitu PT Tosalina Furniture di Desa Butuh, Bengawan Solo Garment, PT Panca Prima Eka Brothers, CV Cahaya Nugraha Jati (www.boyolalikab.go.id).

Perkembangan Desa Butuh mengalami kemajuan yang pesat, salah satunya disebabkan banyaknya industri yang mulai membangun kawasan produksinya di daerah tersebut, misalnya PT Pan Brothers Tbk, Pilar Sejati Sejahtera, dll. Dampak dari berdirinya pabrik-pabrikbaru begitu 
signifikan, dahulu Desa Butuh merupakan salah satu desa yang tanahnya kering dan tandus serta kurang produktif, bahkan untuk irigasi maupun kebutuhan air seharihari mengalami kesulitan sehingga menyebabkan harga jual tanah di daerah tersebut rendah dan perekonomiannya hanya berladang dan berternak sapi perah. Pembangunan pabrik-pabrik tersebut diharapkan dapat meningkatkan lapangan pekerjaan di Kabupaten Boyolali pada khususnya, sehingga angka pengangguran bisa dikurangi. Pada tahun 2010, data mengenai jumlah pencari kerja adalah sebanyak 234.797 orang yang mengalami kenaikan jika dibandingkan tahun 2008 yang sejumlah 155.134 orang. Timbulnya kawasan industri di Desa Butuh Kecamatan Mojosongo Kabupaten Boyolali tersebut meningkatkan aktivitas perekonomian masyarakat di sekitar kawasan industri tersebut. Rizki (2007) dalam penelitiannya mengambil kesimpulan bahwa perkembangan industri secara langsung maupun tidak akan berdampak pada perkembangan suatu wilayah. Lokasi industri akan menarik aktivitas perumahan dan perdagangan, karena melibatkan tenaga kerja dan bahan baku dari luar wilayah.

Penelitian ini bertujuan untuk menganalisis dampak keberadaan kawasan industri di Desa Butuh Kecamatan Mojosongo Kabupaten Boyolali terhadap peningkatan aktivitas perekonomi dan keinginan berwirausaha masyarakat di Desa Butuh Kecamatan Mojosongo Kabupaten Boyolali.

\section{Perumusan Masalah}

Perumusan masalah dalam penelitian ini adalah :

a. Bagaimanakah dampak keberadaan kawasan industri di Desa Butuh Kecamatan Mojosongo Kabupaten Boyolali terhadap peningkatan aktivitas perekonomomian masyarakat di sekitarnya?

b. Apakah keberadaan kawasan industri di Desa Butuh Kecamatan Mojosongo
Kabupaten Boyolali dapat mengurangi jumlah pengangguran, serta meningkatkan tingkat pendidikan dan kesehatan di sekitar kawasan industri tersebut?

c. Apakah terdapat perbedaan terhadap pendapatan dan pengeluaran masyarakat di Desa Butuh Kecamatan Mojosongo Kabupaten Boyolali sesudah adanya kawasan industri tekstil tersebut?

d. Bagaimanakah dampak keberadaan kawasan industri tekstil di Desa Butuh Kecamatan Mojosongo Kabupaten Boyolali terhadap keputusan untuk berwirausaha di sekitar kawasan industri tersebut?

\section{Tinjauan Pustaka}

a. Teori Industri

Industri merupakan sekumpulan perusahaan yang menjual produk yang sama atau yang berhubungan dengan produk tersebut. Industri adalah suatu kegiatan ekonomi yang melakukan kegiatan mengubah suatu barang dasar secara mekanis, kimia, atau dengan tangan sehingga menjadi barang jadi atau setengah jadi dan atau barang yang kurang nilainya menjadi barang yang lebih tinggi nilainya, dan sifatnya lebih dekat kepada pemakaian terakhir (Indra, 2010:52). Pengertian lain tentang industri adalah suatu usaha atau kegiatan pengolahan bahan mentah atau setengah jadi menjadi barang jadi yang mempunyai nilai tambah untuk memperoleh keuntungan.

Pengertian industri menurut BPS (www.bps.go.id) adalah cabang kegiatan ekonomi, sebuah perusahaan atau badan usaha sejenisnya dimana tempat seseorang bekerja. Kegiatan ini diklasifikasikan berdasarkan Klasifikasi Lapangan Usaha Indonesia (KLUI). Sedangkan industri pengolahan adalah suatu kegiatan ekonomi yang melakukan kegiatan mengubah barang dasar (bahan mentah) menjadi barang jadi/setengah jadi dan atau dari barang yang kurang nilainya menjadi barang yang lebih 
tinggi nilainya, baik secara mekanis, kimiawi dengan mesin ataupun dengan tangan.

Industri menurut jumlah tenaga kerjanya dapat dibedakan menjadi industri rumah tangga, industri kecil, menengah dan besar. Industri rumah tangga adalah industri yang mempunyai tenaga kerja antara 1-4 orang. Industri mikro adalah industri yang jumlah tenaga kerjanya antara 5-19 orang. Industri menengah adalah industri yang jumlah tenaga kerjanya antara 20-99 orang dan industri besar adalah industri yang jumlah tenaga kerjanya lebih dari 100 orang.

\section{b. Pengertian Kewirausahaan}

Wirausaha berasal dari kata wira dan usaha, wira berarti gagah berani. Apabila digabungkan dengan kata usaha berarti wirausaha adalah orang yang gagah berani untuk melakukan usaha. Drucker (1985) mengartikan kewirausahaan sebagai semangat, kemampuan,sikap dan perilaku individu dalam menangani usaha (kegiatan) yang mengarah pada upaya mencari, menciptakan, menerapkan cara kerja, teknologi, dan produk baru dengan meningkatkan efisiensi dalam rangka memberikan pelayanan yang lebih baik dan atau memperoleh keuntungan yang lebih besar.

Secara lebih luas, kewirausahaan adalah padanan kata dari entrepreneurship dalam bahasa Inggris, unternehmer dalam bahasa Jerman, ondernemen dalam bahasa Belanda. Dala bahasa Perancis, entrepende mempunyai arti peuang, pengambil resiko, kontraktor, pengusaha dan pencipta yang menjual hasil ciptaannya (Hendro, 2011: 29).

Kewirausahaan adalah kemampuan kreatif dan inovatif yang dijadikan dasar, kiat dan sumber daya untuk mencari peluang menuju sukses. Dengan kata lain, kewirausahaan merupakan suatu kemampuan dalam menciptakan nilai tambah di pasar melalui proses pengelolaan sumber daya dengan cara-cara baru dan berbeda (Suryana, 2003: 1-2).
Setiap orang yang berfikir kreatif dan inovatif bisa dikategorikan sebagai wirausahawan. Proses kewirausahaan diawali dengan proses imitasi dan duplikasi, yang terus melalui proses pengembangan dan akhirnya bisa menciptakan sesuatu yang baru dan berbeda.

Menjadi seorang wirausaha ternyata dapat didorong oleh beberapa faktor, yaitu faktor personal, faktor lingkungan, faktor sosiologis, dan faktor ketersediaan sumber daya.

Faktor personal sebagai salah satu faktor yang mendorong berwirausaha, yang menekankan bahwa independensi merupakan motif yang utama dalam mendirikan usahanya sendiri. Wirausahawan adalah orang-orang yang berani mengambil resiko, pandai beradaptasi dengan perubahan, dan membangun kekuatan pribadi. Wirausahawaan adalah orang-orang yang optimis, ketika melihat masalah menjadi peluang.

Faktor lingkungan mempunyai peran yang signifikan dala pembentukan jiwa kewirausahaan. Salah satu factor lingkungan yang berperan besar dalam membentuk jiwa kewirausahaan adalah budaya. Apabila kewirausahaan dianggap mulia atau mempunyai derajat yang tinggi dalam system sebuah budaya, maka seorang wirausahawan mempunyai kedudukan yang terhormat di suatu masyarakat. Dan dengan budaya tersebut akan menghasilkan banyak wirausahawan baru.

Faktor sosiologis tergantung kepada kondisi sosial yang bisa mempengaruhi seseorang untuk melakukan usaha atau menjadi wirausahawan. Beberapa kondisi sosial tersebut adalah keterbatasan pengembangan karier, tanggung jawab keluarga, dan lain-lain yang bisa memotivasi seseorang untuk memperoleh kehidupan yang lebih baik dengan cara menjadi wirausahawan.

Faktor ketersediaan sumber daya adalah hal yang sangat penting, termasuk 
ketersediaan Sumber Daya Manusia (SDM) dengan pengalaman dan ketrampilan yang sesuai.

\section{METODE PENELITIAN}

Data yang dibutuhkan dalam penelitian ini adalah data primer dan data sekunder baik untuk data kualitatif maupun kuantitatif.. Sampel dari penelitian ini adalah masyarakat di desa Butuh Kecamatan Mojosongo Kabupaten Boyolali yang berada di sekitar kawasan industri tersebut. Jumlah penduduk Desa Butuh adalah sebanyak 3.138 jiwa. Dengan menggunakan rumus Slovin untuk mencari jumlah sampel, maka diperoleh hasil perhitungan sebagai berikut:

$$
n=\frac{N}{1+n e^{2}}
$$

Dimana :

$\mathrm{n}=$ jumlah sampel

$\mathrm{N}=$ jumlah populasi

$\mathrm{e}=$ batas toleransi kesalahan

Berdasarkan rumus Slovin diatas, maka perhitungan sampelnya adalah sebagai berikut :

$$
n=\frac{3138}{1+3138(0,10)^{2}}=96
$$

Jumlah responden yang akan dicari adalah sebanyak 96 orang, yang dibulatkan menjadi 100 orang responden untuk diminta mengisi kuesioner penelitian.

Dalam penelitian ini data kuantitatif dianalisis secara tabulasi dan statistik deskriptif dengan menggunakan uji dua sampel berpasangan dan logit. sedangkan data kualitatif dianalisa secara deskriptif studi kasus yaitu dengan mendiskripsikan, kemudian memberikan penafsiran-penafsiran dengan interpretasi rasional yang memadai terhadap fakta-fakta yang diperoleh di lapangan.

\section{Definisi Operasional}

a. Penggangguran

Adalah penduduk yang bekerja kurang dari 35 jam seminggu (Sakernas, 2007). Sedangkan menurut
BPS, pengangguran adalah penduduk yang tidak bekerja tetapi sedang mencari pekerjaan atau sedang mempersiapkan suatu usaha baru atau penduduk yang tidak mencari pekerjaan karena tidak mungkin mendapatkan pekerjaan, dan penduduk yang tidak aktif encari pekerjaan dengan alasan sudah mempunyai pekerjaan tetapi belum mulai bekerja, yang dihitung dalam satuan orang.

b. Pendapatan

Adalah hasil dari aktivitas bisnis, seperti pendapatan sewa atau penjualan (Albertus Ong), yang dihitung dalam satuan rupiah.

c. Pengeluaran

Adalah semua pengeluaran yang digunakan untuk membeli barang dan jasa, yang dihitung dalam satuan rupiah.

d. Pendidikan

Pendidikan yang berhasil ditamatkan dihitung dengan tahun sukses, masa lama sekolah.

e. Tanggungan Keluarga

Jumlah anggota keluarga yang masih menjadi tanggungan atau dibiayai oleh responden, yang dihitung dalam satuan orang.

f. Status perkawinan

Status perkawinan responden ditunjukkan dengan status kawin atau tidak kawin

g. Usia

Usia responden, dihitung dengan tahun.

\section{Teknik Analisa Data}

\section{a. Uji Dua Sampel Berpasangan (Paired Samples T Test)}

Uji ini dipergunakan untuk mengetahui ada tidak nya perbedaan rata-rata antara dua kelompok sampel yang berpasangan (berhubungan). Maksudnya di sini adalah sebuah sampel tetapi mengalami dua perlakukan yang berbeda (Priyatno, 2010; 37), dan disini perlakuan yang berbeda adalah sebelum dan sesudah ada kawasan industri.

Dalam pengujian yang dilakukan peneliti membandingkan 
antara pendapatan sebelum dan sesudah adanya kawasan industri tersebut dan juga membandingkan antara pengeluaran penduduk Desa Butuh sebelum dan sesudah adanya industri tersebut.

\section{b. Analisis Regresi Logit}

Dampak keberadaan kawasan industri di Desa Butuh menimbulkan keinginan untuk berwirausaha. Untuk melihat faktor-faktor yang mempengaruhi keinginan berwirausaha masyarakat di sekitar kawasan industri di Desa Butuh Kecamatan Mojosongo Kabupaten Boyolali dapat dijabarkan dengan persamaan sebagai berikut :

$Y=\beta o+\beta_{1} X_{1}+\beta_{2} X_{2}+\beta_{3} X_{3}+\beta_{4} X_{4}+\beta_{5} X_{5}+$ ei

Dimana :

$\mathrm{Y}=$ merupakan variabel Dummy, setelah adanya kawasan industri dibedakan menjadi

D1 = Wirausaha

D2 = Tidak berwirausaha

$\mathrm{X} 1=$ Pendidikan

$\mathrm{X} 2$ = Tanggungan Keluarga

$\mathrm{X} 3=$ Status Perkawinan

$\mathrm{X} 4$ = Usia

$\mathrm{X} 5$ = Pengeluaran

$\mathrm{X} 6=$ Pendapatan

$\mathrm{Bo}=$ Konstanta

$\beta_{1} \beta_{2}, \beta_{3}, \beta_{4}=$ Koefisien regresi

ei $=$ Variabel pengganggu

Model yang digunakan adalah Analisis Regresi dengan menggunakan metode Ordinary Least Square ( OLS ) Logit.

\section{HASIL DAN PEMBAHASAN}

\section{Dampak Keberadaan Kawasan Industri Di Desa Butuh Terhadap Peningkatan Aktivitas Perekonomian Masyarakat.}

Keberadaan kawasan industri di Desa Butuh, terutama setelah berdirinya pabrik PT. Pan Brothers Tbk, Pilar Sejati Sejahtera Tbk di Desa Butuh membuat perekonomiannya kian menggeliat. Daerah tersebut dipilih oleh para investor karena harga tanahnya yang masih lumayan murah, dan oleh penduduk setempat hanya digunakan untuk berladang saja karena tekstur tanahnya yang cenderung tandus.

Selain karena faktor tanah yang murah, ada hal lain yang menyebabkan para investor mendirikan pabriknya di wilayah Boyolali. Salah satu sebabnya adalah tingkat UMR yang sudah begitu tinggi di wilayah Jakarta dan Jawa Barat sehingga mendorong investor untuk beralih ke wilayah Jawa Tengah. Tingkat UMR di Jawa Tengah jauh lebih rendah jika dibandingkan dengan tingkat UMR yang ada di Jakarta dan Jawa Barat. UMR Jakarta pada tahun 2013 sudah mencapai Rp. 2.200.000,- juta, sedangkan UMR Semarang adalah Rp 1.209.100,- dan UMR di Boyolali adalah sebesar Rp. 895.000,-

Di Desa Butuh Kabupaten Boyolali merupakan salah satu desa yang mendapatkan dampak dari perpindahan investor tersebut. PT. Pan Brothers Tbk merupakan pabrik yang pertama berdiri di Tangerang semenjak tahun 1980 dan pada tahun 2007 melakukan ekspansi ke daerah Sragen dan Boyolali. Kapasitas produksinya lebih besar pabrik di daerah Boyolali daripada Tangerang. Pan Brothers Tbk merupakan perusahaan yang bergerak pada industri garment, dan mulai masuk dalam pasar saham semenjak tahun 1990.

Nilai ekspor dari produk yang dihasilkan PT. Pan Brothers Tbk cukup tinggi, tingginya nilai ekspor tersebut membuat perusahaan tersebut terus berproduksi. Jumlah tenaga kerja yang dibutuhkan pun terus meningkat. Peningkatan permintaan tenaga kerja membuat daerah di Desa Butuh juga ikut bergeliat.

Selain PT. Pan Brothers Tbk, di Desa Butuh juga terdapat pabrik PT. Pilar Sejati Sejahtera. Perusahaan tersebut juga bergerak dalam bidang industri garment yang produknya $100 \%$ di ekspor ke luar negeri.

Perkembangan Desa Butuh setelah berdirinya beberapa industri tersebut membuat perekonomiannya lebih berkembang. Kawasan di pinggir jalan 
sudah mempunyai nilai jual yang tinggi, karena tanah yang berada di sekitar pabrik atau kawasan industri tersebut sudah beralih fungsi menjadi kawasan kios pertokoan dan sarana lainnya yang menyediakan keperluan bagi pekerja yang bekerja di pabrik-pabrik di Desa Butuh.

Indikator kemajuan perekonomian di suatu wilayah bisa dilihat dari beberapa hal, diantaranya adalah banyaknya aktivitas ekonomi masyarakat. Aktivitas ekonomi muncul karena banyaknya permintaan baik barang dan jasa di sekitar wilayah tersebut. Dibangunnya pabrik-pabrik industri menyebabkan permintaan terhadap pangan,sandan dan tempat tinggal meningkat. Tenaga kerja yang bekerja di kawasan industri tersebut tidak hanya berasal dari daerah sekitar pabrik. Tetapi banyak yang berasal dari luar wilayah. Kebutuhan akan tempat tinggal mengalami peningkatan, lahan-lahan kosong akhirnya dijadikan rumah kos-kosan. Penduduk desa menangkap peluang dari kelebihan permintaan akan tempat tinggal ini. Lahan yang dahulu tandus sekarang sudah beralih fungsi menjadi rumah kos-kosan. Penghasilan yang diperoleh dari berkebun yang jumlahnya tidak pasti sudah diganti dengan penghasilan bulanan yang diperoleh oleh para pemilik rumah kos.

Permintaan tempat tinggal membawa efek lain, yaitu terjadi peningkatan terhadap penyediaan makanan. Warungwarung makan juga banyak bermunculan. Banyak data yang diperoleh dari responden yang memutuskan untuk membuka warung atau tempat makan. Prospeks usaha tersebut juga menguntungkan. Para karyawan pabrik industri memang memperoleh jatah makan satu kali, tapi tak sedikit pu;a para karyawan tersebut yang memutuskan untuk membeli makan di sekitar wilayah industri. Bagi tenaga kerja yang memilih tinggal di rumah kos-kosan, kebutuhan akan tempat makan begitu penting. Mereka tidak banyak mempunyai waktu untuk memasak masakan sendiri. Selain membutuhkan waktu yang relatif lama, mereka juga menginginkan kepraktisan.

Kebutuhan akan perlengkapan seharihari bisa diperoleh di warung kelontong yang bermunculan di daerah tersebut. Beberapa penduduk yang berada dikawasan industri itu ada yang memutuskan untuk membuka toko kelontong. Tidak dibutuhkan keahlian spesifik, hanya modal dan ketekunan, ternyata mampu untuk meningkatkan pendapatan yang mereka peroleh. Bahkan dikawasan tersebut, muncul satu minimarket Alfamart yang menangkap peluang untuk ekspansi usahanya.

$$
\text { Jasa laundry mengalami }
$$
perkembangan yang sangat pesat di Desa Butuh. Dahulu sebelum ada kawasan industri tersebut, belum ada jasa laundry di daerah tersebut. Melihat karakteristik penduduk yang mempunyai banyak waktu senggang, biasanya penduduk di daerah tersebut mencuci pakaiannya sendiri. Setelah adanya kawasan industri, tenaga kerja yang tinggal di rumah kos membutuhkan jasa laundry. Waktu senggang yang mereka punyai sedikit, karena apabila mereka bekerja dengan jam kerja normal maka upah yang mereka peroleh hanya sebesar UMR Boyolali. Tetapi apabila mereka mengambil jam kerja lembur, maka penghasilan yang mereka peroleh jauh lebih banyak. Konsekuensinya adalah waktu senggang yang mereka punyai lebih sedikit, dan waktu senggang tersebut kebanyakan digunakan untuk istirahat. Maka berawal dari inilah, kebutuhan akan jasa laundry mengalami peningkatan yang sangat signifikan.

Counter pulsa/ HP juga banyak bermunculan di sekitar kawasan tersebut. Di era teknologi sekarang ini, kebutuhan akan pulsa sudah masuk dalam kebutuhan primer. Para penyedia jasa ini mempermudah akses bagi tenaga kerja yang bekerja di kawasan industri di Desa Butuh.

Peluang di bidang kesehatan pun ditangkap oleh penduduk di Desa Butuh, 
dengan cara mendirikan apotik dan praktik dokter. Ada satu apotik dan juga satu tempat praktik dokter umum dan dokter gigi. Jadi masyarakat di sekitar wilayah industri tersebut tidak perlu pergi jauh untuk membeli obat atau ketika ingin ke dokter. Gambaran adanya apotik dan tempat praktik doker tersebut juga mengandung arti bahwa daya beli masyarakat di sekitra kawasan industri juga mengalami peningkatan.

Lembaga keuangan pun juga ada di sekitar kawasan industri, peluang-peluang yang ada dengan segera ditangkap oleh para penyedia barang dan jasa. Jasa di bidang keuangan pun ada untuk menfasilitasi antara masyarakat yang mempunyai kelebihan dana dan masyarakat yang kekurangan dana. Manusia mempunyai keinginan untuk memaksimalkan kepuasannya. Salah satu kepuasan diperoleh ketika mereka mengkonsumsi barang yang bersifat kebutuhan sekunder bahkan mewah. Kebutuhan sekunder atau mewah itu kadang mereka peroleh dengan cara kredit. Lembaga keuangan menangkap peluang tersebut, dengan jaminan bahwa para pekerja mendapatkan gaji dari pabrik tempatnya bekerja, maka dana pun bisa mereka dapatkan dari lembaga keuangan tersebut.

Jasa lain yang ada di sekitar kawasan industri tersebut adalah bengkel sepeda motor. Sepeda motor merupakan sarana transportasi utama yang dipilih oleh para pekerja pabrik. Disaping adanya kendaraan/bus jemputan, tapi rutenya belum mencakup semua asal/ tempat tinggal para pekerja pabrik. Pilihan menggunakan sepeda motor yang lebih fleksibel, karena kapanpun mereka berangkat atau menambah jam kerja lembur bisa dilakukan. Kendala terhadap kerusakan sepeda motor inilah yang ditangkap oleh para pelaku usaha dengan cara mendirikan bengkel sepeda motor. Usaha untuk mendirikan bengkel sepeda motor memang membutuhkan keahlian spesifik mengenai mesin sepeda motor.
Selain menwarkan perbaikan, bengkel tersebut juga menawarkan jasa untuk mengganti oli dan perlengkapan sparepart lainnya.

Fenomena kendaraan sepeda motor sebagai salah satu alat transportasi utama meningkatkan permintaan terhadap tempat untuk menitipkan kendaraan tersebut. Kawasan di dalam pabrik ternyata tempat penitipan sepeda motornya masih jauh dari kapasitas sepeda motor yang dibawa oleh pekerja. Ini menimbulkan banyaknya tempat penitipan sepeda motor yang berada di luar kawasan pabrik. Dari lahan kosong, dengan modal adanya atap baik yang terbuat dari seng atau asbes sudah menjadi tempat yang layak untuk penitipan sepeda motor. Bahkan dari pendapatan jasa penitipan sepeda motor ini, para pelaku usaha penitipan sepeda motor ini bisa melakukan ekspansi ke bisnis di bidang lain seperti membuka toko sepatu, toko kelontong atau membuka usaha rumah kos.

Berikut disajikan data mengenai peningkatan aktivitas perekonomian masyarakat akibat adanya kawasan industri di Desa Butuh Kecamatan Mojosongo.

\section{Tabel 1. Data Jumlah Aktivitas Perekonomian Di Desa Butuh}

\begin{tabular}{lc}
\hline Aktivitas Perekonomian & Jumlah \\
\hline Warung Makan & 47 \\
Warung Kelontong & 27 \\
Counter Pulsa/ HP & 9 \\
Apotik & 1 \\
Rumah Kos & $>20$ \\
Bengkel Motor & 3 \\
Lembaga Keuangan & 2 \\
Salon & 2 \\
Laundry & 4 \\
Praktik Dokter & 2 \\
\hline Sumber : Survei Lapangan $(2013)$
\end{tabular}

Sumber : Survei Lapangan (2013) 
Dampak Keberadaan Kawasan Industri di Desa Butuh Terhadap Pengurangan Jumlah Pengangguran, serta Peningkatan Tingkat Pendidikan dan Kesehatan di Sekitar Kawasan Industri

Aktivitas perekonomian yang terjadi sebagai dampak keberadaan kawasan industri di Desa Butuh membawa beberapa perubahan terhadap masyarakat di sekitar kawasan industri tersebut. Beberapa perubahan positif adalah kemampuan para penduduk di sekitar wilayah industri itu menangkap peluang berwirausaha. Ada berbagai macam usaha yang mereka lakukan, diantaranya adalah membuka warung makan, warung kelontong, mendirikan rumah kos dan tempat penitipan kendaraan bermotor, membuka usaha laundry, bengkel sepeda motor bahkan ada pula usaha salon di sekitar kawasan industri. Di bidang kesehatan, ada pula yang mendirikan apotik dan tempat praktik dokter umum dan dokter gigi, serta ada pula yang lembaga keuangan yang ekspansi ke daerah tersebut.

Dahulu, masyarakatnya hanya sebagai peternak saja. Kota Boyolali merupakan sentra penghasil susu,mereka mengandalkan produksi susu yang dihasilkan oleh sapi peliharaan mereka. Susu sapi itu diambil tiap sore oleh KUD Mojosongo yang letaknya tidak terlalu jauh dari Desa Butuh. Kualitas susu yang disetor harus sesuai dengan kualitas standar Industri Pengolahan Susu (IPS), dengan harga per liter berkisar antara Rp. 2.800 - 3.000. Ada beberapa permasalahan yang biasa dialami oleh peternak sapi perah, yaitu ketidakstabilan harga pakan ternak. Harga pakan ternak pada musimmusim tertentu sangat fluktuatif, sehingga membuat keuntungan yang diperoleh para peternak itu pun berkurang. Atau ketika mereka beralih ke pakan ternak yang lainnya, maka produksi susu yang dihasilkan tidak sesuai dengan kualitas standar yang ditetapkan oleh IPS sehingga tidak bisa diterima oleh KUD Mojosongo.
Bagi yang dahulu hanya berladang saja, dengan kondisi tanah yang tandus maka hasil yang diperoleh tidak bisa dijadikan sebagai pemasukan yang utama baginya. Ladang tersebut biasa ditanami dengan singkong dan pohon pepaya. Masa panen singkong yang relatif lama, yaitu mencapai usia 9-10 bulan membuat ladang tersebut tidak bisa dijadikan sebagai salah satu sumber utama untuk pemasukan keluarga. Begitu pula dengan buah pepaya, baru bisa dipanen setelah usia 9-12 bulan semenjak penanaman pertama kali. Boyolali selain sebagai sentra susu perah, juga sebagai daerah penghasil pepaya terbesar di Jawa Tengah. Tetapi karena masa panen lama, dan buah yang dihasilkannya pun tidak bisa relatif lama maka para petani pepaya kebanyakan tidak bisa menghasilkan keuntungan yang besar.

Ketika daerah di sekitar tempat tinggalnya didirikan industri, maka mereka mencoba menangkap peluang lain yang lebih menjanjikan. Peluang yang mereka tangkap inilah yang mendorong mereka menjadi wirausahawan, dengan berbagai macam jenis. Ternyata penghasilan yang mereka peroleh dari usaha wiraswasta ini bisa menambah penghasilan sebelumnya atau menjadi masukan utama bagi keluarganya.

Jumlah pengangguran di daerah Boyolali setiap tahun masih mengalami peningkatan terus. Hal ini salah satunya disebabkan oleh angka kelulusan sekolah yang terus meningkat tetapi tidak diimbangi dengan banyaknya lapangan pekerjaan. Industri di Desa Butuh Kecamatan Mojosongo menyerap banyak tenaga kerja, baik tenaga kerja lokal maupun tenaga kerja yang berasal dari luar wilayah. Berdasarkan data yang diperoleh, penyerapan tenaga kerja bagi penduduk yang berada di sekitar kawasan industri jumlahnya lebih sedikit apabila dibandingkan dengan penduduk yang berasal dari luar daerah tersebut. Kecenderungan penduduk di sekitar kawasan industri adalah lebih suka untuk 
berwirausaha memenuhi kebutuhan tenaga kerja yang ada di kawasan industri tersebut dibandingkan menjadi tenaga kerja/ buruh pabrik.

Tambahan pendapatan yang diperoleh oleh masyarakat di sekitar kawasan industri pun bisa mengubah cara berfikir mereka untuk menjadi lebih baik lagi. Ketika pendapatan yang dahulu mereka peroleh adalah pas-pasan, maka akses mereka terhadap pelayanan kesehatan pun terbatas. Setelah adanya industri, dan kebanyakan dari masyarakat melakukan wirausaha maka tambahan pendapatan yang diperoleh juga semakin besar. Ini yang mendorong kemudahan akses mereka terhadap pelayanan kesehatan.

Pentingnya pendidikan ternyata sudah menjadi prioritas masyarakat untuk meningkat kesejahteraan mereka. Memperoleh kehidupan yang lebih baik itu yang dicita-citakan setiap manusia di muka bumi ini. Begitu pula dengan masyarakat sekitar kawasan industri di Desa Butuh Kecamatan Mojosongo Kabupaten Boyolali. Berdasarkan kuesioner yang kami sebar, diperoleh hasil bahwa sebagian besar atau hampir $48 \%$ responden bercita-cita atau mempunyai harapan untuk bisa menyekolahkan anaknya hingga jenjang perguruan tinggi, baik sebelum maupun setelah adanya industri. Sebanyak $16 \%$ mempunyai harapan bisa menyekolahkan anaknya hingga jenjang perguruan tinggi sesudah adanya kawasan industri tersebut. Karena pendapatan yang mereka dapatkan mengalami peningkatan, dahulu sebelum adanya kawasan industri harapan mereka hanya bisa menyekolahkan anak hingga jenjang SMA saja. Sebanyak $7 \%$ responden juga mempunyai pengharapan bisa menyekolahkan anaknya hingga jenjang perguruan tinggi dari sebelumnya yang berharap anaknya sekolah sampai dengan tingkat SMP saja. Dan sisanya kebanyakan mereka mengharap dengan adanya kawasan industri tersebut yang memberikan peluang masyarakat untuk terus berwirausaha, maka mereka bisa menyekolahkan anaknya sampai dengan tingkatan yang lebih tinggi dari harapan sebelumnya ketika pendapatan yang mereka peroleh terbatas.

Berdasarkan hasil 100 kuesioner yang sudah tersebar, terdapat hasil bahwa ada $32 \%$ responden memilih ke dokter ketika sakit baik sebelum atau sesudah adanya kawasan industri tersebut. Yang artinya, masyarakat di sekitar kawasan industri tersebut sebenarnya akses terhadap kesehatannya relatif sudah mudah. Sebanyak $29 \%$ responden yang mempercayakan Puskesmas sebagai rujukan tempat berobat. Biaya yang cenderung lebih murah tetapi dengan pelayanan yang memuaskan menjadi pertimbangan mereka. Sebanyak $12 \%$ responden memilih berobat ke rumah sakit, baik sebelum maupun setelah adanya industri. Pertimbangan yang mereka ambil adalah karena kelengkapan dokter spesialis dan peralatan yang ada di rumah sakit. Sebanyak 7\% responden memilih pergi ke mantri kesehatan apabila mereka sakit, dengan alasan sudah terbiasa berobat ke mantri dan biasanya obat yang diberikan relatif murah tetapi manjur. Sisanya sebanyak $5 \%$ respon yang berubah tempat berobatnya, ketika sebelum adanya industri mereka apabila sakit berobat ke puskesmas, tetapi setelah adanya industri mereka memilih pergi ke dokter. Sebanyak $3 \%$ responden yang berobat ke bidan ketika belum ada industri di Desa Butuh, dan setelah adanya kawasan industri mereka pindah berobat ke dokter. Peningkatan pendapatan yang mengubah gaya hidup mereka, biasanya untuk mencari tempat berobat yang lebih baik.

\section{Hubungan Antara Keberadaan Kawasan Industri di Desa Butuh Kecamatan Mojosongo Kabupaten Boyolali terhadap Pendapatan dan Pengeluaran Masyarakat Sekitar Kawasan Industri}

Keberadaan suatu industri akan memberikan pengaruh terhadap pendapatan 
dan pengeluaran penduduk yang berada diwilayah tersebut. Baik secara langsung maupun tidak langsung akan berkaitan dengan perekonomian dalam hal ini adalah pendapat dan pengeluaran dari masyarakat setempat.

a. Uji Dua Sample Berpasangan Untuk Pendapatan

Uji ini dipergunakan untuk melihat apakah terdapat perbedaan pendapatan antara sebelum dan sesudah adanya kawasan industri di Desa Butuh Kecamatan Mojosongo Kabupaten Boyolali.

Hipotesis :

$\mathrm{H}_{0}=$ Tidak terdapat perbedaan pendapatan sebelum dan sesudah adanya kawasan industri di Desa Butuh Kecamatan Mojosongo Kabupaten Boyolali.

$\mathrm{H}_{1}=$ Terdapat perbedaan pendapatan sebelum dan sesudah adanya kawasan industri di Desa Butuh Kecamatan Mojosongo Kabupaten Boyolali.

Kriteria hasil uji adalah :

$\mathrm{H}_{0}$ diterima jika nilai signifiknasi hasil pengujian $>0,05$.

$\mathrm{H}_{1}$ diterima jika nilai signifikansi hasil pengujian $<0,05$.

Hasil analisis menggunakan uji t terhadap pendapatan sebelum dan pendapatan setelah adanya kawasan industri di Desa Butuh Kecamatan Mojosongo Kabupaten Boyolali adalah sebesar $-4,767$ dimana nilai ini < dari nilai t tabel $(1,980)$. Hal tersebut berarti $\mathrm{H}_{1}$ diterima, ada perbedaan tingkat pendapatan antara sebelum dan sesudah adanya kawasan industri di Desa Butuh Kecamatan Mojosongo Kabupaten Boyolali.

b. Uji Dua Sample Berpasangan Untuk Pengeluaran

Uji ini dipergunakan untuk melihat apakah terdapat perbedaan pengeluaran antara sebelum dan sesudah adanya kawasan industri di Desa Butuh Kecamatan Mojosongo Kabupaten Boyolali.

Hipotesis :

$\mathrm{H}_{0}=$ Tidak terdapat perbedaan pengeluaran sebelum dan sesudah adanya kawasan industri di Desa Butuh Kecamatan Mojosongo Kabupaten Boyolali.
$\mathrm{H}_{1} \quad=$ Terdapat perbedaan pengeluaran sebelum dan sesudah adanya kawasan industri di Desa Butuh Kecamatan Mojosongo Kabupaten Boyolali.

Hasil analisis menggunakan uji t terhadap pengeluaran sebelum dan sesudah adanya kawasan industri di Desa Butuh Kecamatan Mojosongo Kabupaten Boyolali adalah sebesar $-4,769$ dimana nilai ini $<$ dari nilai t tabel $(1,980)$. Hal tersebut berarti $\mathrm{H}_{1}$ diterima, ada perbedaan tingkat pengeluaran antara sebelum dan sesudah adanya kawasan industri di Desa Butuh Kecamatan Mojosongo Kabupaten Boyolali.

\section{Analisis Faktor yang Mempengaruhi Keinginan Berwirausaha Masyarakat di Desa Butuh Kecamatan Mojosongo Kabupaten Boyolali.}

Hasil olahan data mengenai factorfaktor yang mempengaruhi keinginan berwirausaha masyarakat yang berada di sekitar kawasan industri Desa Butuh Kecamatan Mojosongo Kabupaten Boyolali setelah dicari nilai odd rationya tersaji sebagai berikut :

Tabel 2. Nilai Odds Ratio Variabel Yang Mempengaruhi Keinginan Berwirausaha

\begin{tabular}{lcc}
\hline \multicolumn{1}{c}{ Variabel } & Odd Ratio & Probabilitas \\
\hline C & -39.537739 & 0.722878362 \\
Pendidikan & 13.032753 & 0.083602557 \\
Jumlah & & \\
Keluarga & 6.204323 & 0.729449762 \\
Status & 67.362132 & 0.283635169 \\
Usia & -2.037810 & 0.328633498 \\
Pengeluaran & 0.000076 & 0.097335764 \\
Pendapatan & -0.000036 & 0.058911586 \\
\hline
\end{tabular}

Sumber : Data Primer diolah (2013)

Berdasarkan tabel 2, maka bisa diambil kesimpulan sebagai berikut :

Koefisien regresi dari variabel pendidikan adalah sebesar 0.12250 , dengan probablilitas sebesar 0.0836 maka variabel pendidikan pada taraf signifikansi $10 \%$ 
mempunyai pengaruh terhadap keinginan berwirausaha. Odds ratio yang diperoleh adalah sebesar 13.032753 yang berarti apabila pendidikan meningkat satu tingkat atau satu jenjang, maka probabilitas kemungkinan keinginan untuk berwirausaha naik sebesar 13,03\%.

Koefisien regresi variabel jumlah tanggungan keluarga adalah sebesar 0.060194631 , dengan probabilitas sebesar 0.7295 maka dapat disimpulkan bahwa variabel jumlah tanggungan keluarga tidak berpengaruh terhadap keinginan berwirausaha masyarakat di Desa Butuh Kecamatan Mojosongo pada taraf signifikansi $10 \%$.

Hasil olahan data menunjukkan koefisien status pernikahan adalah sebesar 0.514989732. Sedangkan tingkat probabilitasnya aalah sebesar 0.2836, yang berarti pada taraf signifikansi $10 \%$ variabel status pernikahan tidak mempengaruhi terhadap keinginan berwirausaha dari masyarakat di sekitar kawasan industri di Desa Butuh Kecamatan Mojosongo.

Koefisen regresi dari variabel usia adalah sebesar -0.020588601 dengan odds ratio sebesar -2.037810. Probabilitas variabel usia adalah sebesar 0.328633498 . Maka dapat disimpulkan pada taraf signifikasi $10 \%$, variabel usia tidak berpengaruh terhadap keinginan berwirausaha masyarakat yang berada di sekitar kawasan industri di Desa Butuh Kecamatan Mojosongo Kabupaten Boyolali.

Koefisien regresi variabel pengeluaran adalah sebesar 0.0000007 dengan probabilitas sebesar 0.097335764 dan odds ratio sebesar 0.000076 . Maka dapat disimpulkan pada taraf signifikansi $10 \%$, variabel pengeluaran berpengaruh terhadap keinginan masyarakat untuk berwirausaha. Adapun arti dari odds ratio tersebut adalah apabila pengeluaran sebelum adanya industri meningkat 1 rupiah, maka kemungkinan keputusan untuk berwirausaha bagi masyarakat di sekitar kawasan industri akan meningkat sebesar 0,000076\%.

Koefisien regresi variabel pendapatan adalah sebesar -0.0000003 dengan probabilitas sebesar 0.058911586. Maka dapat disimpulkan bahwa variabel pendapatan berpengaruh signifikan terhadap keputusan berwirausaha bagi masyarakat yang ada di sekitar kawasan industri pada taraf signifikansi sebesar 10 $\%$. Odds ratio yang diperoleh sebesar 0.000036 , yang mengandung arti apabila pendapatan masyarakat sebelum adanya industri meningkat sebesar 1 rupiah, maka kemungkinan keputusan untuk berwirausaha akan turun sebesar $0,000036 \%$

\section{KESIMPULAN}

1. Perekonomian masyarakat di sekitar kawasan industri di Desa Butuh Kecamatan Mojosongo dengan berdirinya beberapa pabrik membuat semakin berkembang. Masyarakat yang dahulu hanya bertani, beternak dan berladang sekarang sudah banyak yang menangkap peluang untuk berwirausaha. Banyaknya permintaan akan kebutuhan barang dan jasa menyebabkan kawasan di Desa Butuh semakin ramai, dan mendorong masyarakat di sekitar wilayah tersebut untuk membuka warung makan, toko kelontong, rumah kos, jasa laundry, bengkel sepeda motor, bahkan hingga ke apotik, praktik dokter dan salon.

2. Dampak keberadaan kawasan industri di Desa Butuh Kecamatan Mojosongo bisa mengurangi angka pengangguran di desa tersebut. Tenaga kerja yang terserap berasal dari dalam dan luar wilayah Desa Butuh. Tetapi kebanyakan masyarakat di Desa Butuh memilih untuk berwirausaha di sekitar kawasan industri tersebut daripada menjadi buruh pabrik. Tambahan pendapatan yang diperoleh, menggeser cara berfikir masyarakat di sekitar kawasan industri tersebut dalam bidang pendidikan dan 
kesehatan. Di bidang pendidikan, mereka berharap bisa menyekolahkan anaknya hingga jenjang yang paling tinggi sedangkan di bidang kesehatan, dengan adanya tabahan pendapatan dari berwirausaha membuat mereka semakin mudah untuk mendapatkan akses kesehatan yang lebih layak.

3. Terdapat perbedaan pendapatan dan pengeluaran antara sebelum dan sesudah adanya kawasan industri di Desa Butuh Kecamatan Mojosongo Kabupaten Boyolali.

4. Variabel pendidikan, pengeluaran dan pendapatan berpengaruh terhadap keinginan untuk berwirausaha. Sedangkan variabel jumlah tanggungan keluarga, status dan usia tidak berpengaruh terhadap keinginan untuk berwirausaha bagi masyarakat yang berada di sekitar kawasan industri di Desa Butuh Kecamatan Mojosongo Kabupaten Boyolali.

\section{SARAN}

1. Perusahaan yang ada di Desa Butuh, yaitu PT. Pan Brothers dan Pilar Sejati Sejatera hendaknya membuat program CSR yang berupa pelatihan atau pendampingan untuk meningkatkan kemampuan berwirausaha bagi masyarakat di sekitar wilayah industri tersebut.

2. Masyarakat pendatang hendaknya diikutsertakan pada kegiatan sosial yang ada di daerah tersebut untuk menghilangkan adanya batas antara warga pendatang dan warga asli daerah Desa Butuh.

3. Pemerintah Boyolali hendaknya membuat kebijakan untuk menambah ketrampilan, permodalan bagi pelaku wirausaha serta melakukan penataan sehingga tidak terkesan kumuh di sekitar wilayah industri tersebut.

\section{DAFTAR PUSTAKA}

Alma, Buchori , 2007, Kewirausahaan, Alfabeta, Bandung.
Cultural Council of Indiana River County, 2012, The Economics Impact of Creative Industry in Indiana river County in 2010.

Dandekar, C Hemalata, 1983, The Impact of Bombay's Textile on Work of Women From Sugao Village, Third World Planning Review, Volume 5, Number 4/1982: November.

Dumairy, 1996, Perekonomian Indonesia, Erlangga, Jakarta.

http://repository.usu.ac.id/bitstream/1234567 89/23570/3/Chapter\%20II.pdf diakses pada 15 Desember 2012 pukul 22.00 WIB.

Indra Setyo Nugroho, 2010, Dampak Keberadaan Industri Tekstile PT Delta Dunia Tekstil Terhadap Aktifitas Ekonomi Masyarakat Desa Brujul Kabupaten Karanganya, Skripsi, Tidak Untuk Dipublikasikan, UNS.

Irawan dan M. Suparmoko, 1998, Ekonomika Pembangunan, BPFE

Yogyakarta, Yogyakarta.

Nachrowi D. N \& Hardius Usman, 2006, Pendekatan Populer dan Praktis Ekonometrika untuk Analisis Ekonomi dan Keuangan, LP FE UI, Jakarta.

Mubyarto, 1988, Sistem dan Moral Ekonomi Indonesia, LP3ES, Jakarta.

Mudrajat Kuncoro, Artidiatun Adji, Rimawan Pradiptyo, 1997, Ekonomi Industri : Teori, Kebijakan, dan Studi Empiris di Indonesia, Widya Sarana Informatika, Yogyakarta.

Myles, Albert and Garen Evans, 2005, Measuring The Impact of New Industry in Town, Mississippi State University Publication.

Publication. 
Nur Feriyanto, 2004, Profil Industri Kecil Tekstil dan Produk Tekstil (TPT) di Kabupaten Klaten, Jurnal Ekonomi Pembangunan, Vol 9 No 1, Juni 2004, Hal 91-104.

Priyatno, Duwi,. 2010. Paham Analisis Statistik Data Dengan SPSS. PT Buku Seru.

Todaro, Michael, 2006, Ekonomi Pembangunan, Erlangga. Jakarta.Viva Tjafura
Ni'mah, 2012, Analisis Dampak Perusahaan Rokok Alfi Putra Terhadap Kesejahteraan Masyarakat di Desa Gembleb Kecamatan Pogalan Kabupaten Trenggalek, diakses melalui www.um.library.ac.id pada tanggal 2 Desember 2012 pukul 20.05 WIB.

www.antaranews.com

www.boyolalikab.go.id

www.bps.go.id 